Original Contribution

\title{
VOLUNTARY WHEEL RUNNING IS EFFECTIVE ON SUPPRESSING OF OBESITY BUT NOT ON BLOOD PRESSURE AND INSULIN RESISTANCE IN FEMALE RATS FED WITH HIGH FRUCTOSE DIET
}

\author{
P. Tayfur ${ }^{1}$, K. Gökçe Tezel ${ }^{2}$, Ö. Barutçu ${ }^{3}$, S. Yılmaz ${ }^{3}$, E. Ö. Özgür ${ }^{3}$, N. Süt ${ }^{4}$, S. A. \\ $\operatorname{Vardar}^{5^{*}}$ \\ ${ }^{1}$ Department of Physiology, Health Science Institute, Trakya University, Edirne, Turkey \\ ${ }^{2}$ Department of Child Health and Diseases, School of Medicine, Marmara University, Istanbul, Turkey \\ ${ }^{3}$ School of Medicine, Trakya University, Edirne, Turkey \\ ${ }^{4}$ Department of Biostatistics, Medical Faculty, Trakya University, Edirne, Turkey \\ ${ }^{5}$ Department of Physiology, Medical Faculty, Trakya University, Edirne, Turkey
}

Poster presented at the Joint Meeting of the Federation of European Physiological Societies (FEPS) and the Austrian Physiological Society, 13-15 September 2017, Vienna, Austria and orally presented at the 6. Exercise Physiology Symposium, 18-19 May 2017, Edirne, Turkey.

\begin{abstract}
A fructose-rich diet has been known to cause metabolic syndrome effects such as body weight gain, increased blood pressure, blood lipids and glucose levels. The role of voluntary physical activity in these alterations is not known clearly. The aim of this study was to investigate the possible improving effects of voluntary physical activity in rats that were feeding with a fructose-rich diet.

Spraque-Dawley female rats were separated as control $(\mathrm{C} ; \mathrm{n}=7)$, voluntary physical activity $(\mathrm{A} ; \mathrm{n}=7)$, fructose $(\mathrm{F} ; \mathrm{n}=7)$ and fructose+activity $(\mathrm{F}+\mathrm{A} ; \mathrm{n}=7)$ groups. A and $\mathrm{FA}$ groups were kept in cages with running wheels during six weeks. F and FA groups were fed with adding $20 \%$ fructose in drinking water. Body weight was measured weekly and Lee Index was used to determine obesity. At the end of the feeding period serum glucose, insulin and lipid levels were measured by enzymatic method and blood pressure was determined with the tail-cuff method.

Daily voluntary walking distance in $\mathrm{F}+\mathrm{A}$ and A groups were similar during six weeks. Fructose intake induced to increase systolic blood pressure $(\mathrm{p}=0.001)$, diastolic blood pressure $(\mathrm{p}=0.002)$, glucose $(\mathrm{p}=0.041)$, insulin $(\mathrm{p}=0.001)$, cholesterol $(\mathrm{p}=0.001)$, triglyceride $(\mathrm{p}=0.001)$ and liver weight $(\mathrm{p}=0.035)$. The voluntary activity was found effective on the decrease of weight gain $(\mathrm{p}=0.018)$ however we did not observe a significant effect on blood pressure $(\mathrm{p}=0.917)$ and insulin resistance $(\mathrm{p}=0.565)$ following the fructose-rich diet.

We conclude that voluntary activity has preventive effect on obesity but may not to be effective on increased blood pressure and insulin resistance in female rats which were feeding fructose-rich diet during six weeks.
\end{abstract}

Key Words: Exercise, fructose, metabolic syndrome, voluntary physical activity

\section{INTRODUCTION}

Fructose-rich diet causes symptoms of metabolic syndrome such as obesity, dyslipidemia, and hypertension and insulin resistance $(1,2)$. The prevalence of metabolic syndrome in 20 years and older women was reported to be $31.9 \%$ (3). In addition, the

\footnotetext{
*Correspondence to: Selma Arzu Vardar, $M D, P h D$, Trakya University Medical Faculty, Department of Physiology, 22030 Edirne, Turkey, Tel: +90-284-235 76 41 (1426), Fax: +90-284-235 76 52, E-mail: arzuvardar22@hotmail.com,arzuvardar@trakya.edu.tr
}

frequency of metabolic syndrome is higher in persons who are doing less physical activity (4). Experimental studies have been reported that the effects of a long-term fructose-rich diet can be prevented by treadmill exercise $(5,6)$. According to a study by Mostarda et al. (6), treadmill walking exercise for five days a week for 10 weeks decreases weight gain, systolic and diastolic blood pressure, and insulin resistance results from the fructose-rich diet in rats. However, there are few studies on the preventive effects of voluntary wheel running of the weight gain, systolic and diastolic blood pressure, and insulin resistance. 
According to the data of the World Health Organization, $60 \%$ of the world population is not physically active and in recent years, it has led to further investigation of the effects of voluntary physical activity on the body in experimental studies (7). Voluntary activities are intrinsically motivating exercises in both humans and animals (8). In experimental studies, running wheels are used to perform voluntary exercises in rodents (9). The running wheel allows the experimental animals to perform physical activity in their living environments. Voluntarily exercising rats had lower body weight than non-exercising rats (10). In addition, voluntary exercise is reported to reduce cardiovascular complications associated with diabetes (11). A recent study by Rattanavichit et al. (12) showed that voluntary physical activity can increase insulin-mediated glucose transport in muscles and reduce adipose tissue content during a fructose-rich diet in male rats. However, it is stated that there may be gender related changes in this subject and voluntary exercise behavior in female rats could be varied (13). It is reported that this difference may be due to the fact that female rats tend to run more distance than male rats and that food consumption behaviors are different. In the present study, we aimed to investigate the possible improving effects of voluntary physical activity in female rats that were feeding with a high fructose diet. Thus, the effects of voluntary wheel running on body weight, blood pressure, serum lipid, glucose levels and insulin resistance were investigated in female rats receiving fructose in their drinking water $(20 \% \mathrm{w} / \mathrm{v})$ for six weeks in the present study.

\section{MATERIAL AND METHODS}

Animals and interventions: Twenty-eight Sprague-Dawley female rats $(227.21 \pm 12 \mathrm{~g})$ were supplied by the Experimental Animals Unit of Trakya University for this study. All rats were kept in an environment of $55 \%$ humidity, at $21 \pm 2^{\circ} \mathrm{C}$, following a 12:12-h light-dark cycle (lights on from 7:00 AM to 7:00 PM) and each was in separate cages. Rats were randomly divided into four groups: control rats were given reverse osmosis water $(\mathrm{C}, \mathrm{n}=7)$, voluntary physical activity rats given reverse osmosis water and doing voluntary physical activity (A, $\mathrm{n}=7)$, fructose rats receiving liquid fructose $(20 \% \mathrm{w} / \mathrm{v})(\mathrm{F}, \mathrm{n}=7)$ and fructose+voluntary physical activity rats receiving liquid fructose $(20 \% \mathrm{w} / \mathrm{v})(\mathrm{F}+\mathrm{A}$, $\mathrm{n}=7$ ). This study was approved by Trakya
TAYFUR P., et al.

University Animal Experiments Local Ethics Committee (TUHADYEK-2016/21).

All animals were given free access to food (Optima Foods IND. And TRADE CO. INC Bolu, Turkey), and water for six weeks (Table 1). Rats in the $\mathrm{F}$ and $\mathrm{F}+\mathrm{A}$ groups were fed for six weeks by adding $20 \%$ fructose to drinking water passed through the reverse osmosis system. Amounts of fluid intake of all animals in the experimental groups were recorded daily and water consumption was calculated as $\mathrm{mL} /$ day per rat. Rats in the fructose groups were fed with fructose solution (200 g/L) prepared by dissolving standard feed and Dfructose (Sigma-Aldrich, St. Louis, MO, USA) in a ratio of $20 \%$ in drinking water. The fructose solution was prepared daily. In order to prevent bacterial growth in drinking water, both control and fructose groups' water bottles were cleaned with hot water every week. At the end of the feeding period, thiopental (I.E. Ulagay INC Istanbul, Turkey) was given to the rats intraperitoneally $(100 \mathrm{mg} / \mathrm{kg})$ for anaesthesia and afterwards their blood pressures were measured. Thereafter, blood samples were taken from the femoral vein for metabolic examinations.

Body weight measurement: In this study, body weight was measured weekly, and Lee index was used to determine obesity (6) Lee index was calculated by the formula of rats' body weight $(\mathrm{g})^{1 / 3} \times 10 /$ naso-anal length $(\mathrm{mm})$. Total heart weight, right and left ventricular weights, liver and lung weights were measured in all groups. Heart weight $(\mathrm{mg}) /$ tibia length $(\mathrm{mm})$ ratios were determined for cardiac hypertrophy.

Voluntary physical activity: For the voluntary physical activity of rats, a running wheel mounted on the cages and a device for recording the frequency of rotation was used (Atatek Automation End. Product. INC. Tekirdağ, Turkey). Similar to previous studies (14), the dimensions of the rotating wheel were $31.5 \mathrm{~cm}$ in diameter and $10 \mathrm{~cm}$ in width, with a cage height of $7 \mathrm{~cm}$ and a circumference of 1.081 meters. The wheel was removable from the cage and was cleanable. Daily wheel rotations were recorded as clockwise, counter clockwise and total number of revolutions. The rats in the activity groups were kept in cages with rotating wheels for one week before the experiment in order for them to recognize the wheel. Daily wheel activities were determined as $\mathrm{km} /$ day. 
Table 1. The ingredients of standard laboratory feed

\begin{tabular}{lc}
\hline Crude protein (\%) & 24.0 \\
Crude cellulose (\%) & 3.00 \\
Crude fat (\%) & 5.55 \\
Crude ash (\%) & 9.00 \\
Lysine (\%) & 1.35 \\
Methionine (\%) & 0.45 \\
Calcium (\%) & 1.16 \\
Phosphorus (\%) & 0.84 \\
Sodium (\%) & 0.24 \\
Vitamin A (I.U/kg) & 22200 \\
Vitamin D3 (I.U/kg) & 4884 \\
Iodine (calcium iodine anhydride) $(\mathrm{mg} / \mathrm{kg})$ & 0.8 \\
Cobalt (cobalt carbonate monohydrate) $(\mathrm{mg} / \mathrm{kg})$ & 0.15 \\
Copper (copper sulphate pentahydrate) $(\mathrm{mg} / \mathrm{kg})$ & 10 \\
Manganese (manganese oxide) $(\mathrm{mg} / \mathrm{kg})$ & 50 \\
Zinc (zinc oxide) $(\mathrm{mg} / \mathrm{kg})$ & 50 \\
Selenium (sodium selenite) $(\mathrm{mg} / \mathrm{kg})$ & 0.15 \\
\hline
\end{tabular}

Blood pressure determination and metabolic measurements: On the last day of the sixth week of the study, the blood pressure of rats was measured by the method of indirect tailcuff plethysmography (MAY NIBP250, Ankara, Turkey). Systolic blood pressure, diastolic blood pressure, and heart rate averages were calculated by taking 5 measurements from each rat. The abdomens of rats were then cut open and blood samples were taken from femoral veins of the rats for metabolic examinations. Blood samples were centrifuged at $3000 \mathrm{rpm}$ at $+4^{\circ} \mathrm{C}$ for 15 mins (MPW 350R, Poland). Serum glucose, triglyceride, total cholesterol, high-density lipoprotein (HDL) levels were measured by the enzymatic method. Serum levels of insulin (EMD Millipore Corporation, Missouri, USA) were measured by ELISA method. Lowdensity lipoprotein (LDL) was calculated by Friedewald formula (16). Friedewald's formula is given as: LDL cholesterol=Total cholesterol(HDL cholesterol+(TG/5)). Insulin resistance (HOMA-IR) values in rats were calculated by the formula of HOMA-IR: serum insulin $(\mathrm{mmol} / \mathrm{L}) *$ blood glucose $(\mathrm{mmol} / \mathrm{L}) / 22.5(16)$.

Statistical analysis: Values were expressed as mean \pm standard deviation. Two-way analysis of variance (ANOVA) was used to determine the main effects of fructose and activity and the fructose+activity interaction. The mean walking distances of $\mathrm{F}+\mathrm{A}$ and $\mathrm{A}$ groups were compared using Student's t-test. A value of $\mathrm{p}<0.05$ was considered statistically significant.

\section{RESULTS}

When the amount of fluid consumed was measured, it was observed that the rats in fructose groups ( $\mathrm{F}$ and $\mathrm{F}+\mathrm{A}$ ) had higher fluid consumption than the other groups $(\mathrm{C}$ and $\mathrm{A})$ (Table 2). The difference in fluid intake between the first and sixth weeks was caused by fructose consumption ( $p<0.001$ ). Running activity is shown in Figure 1. When the average walking distances of $\mathrm{A}$ and $\mathrm{F}+\mathrm{A}$ group rats were measured in six weeks, there was no difference between $\mathrm{F}+\mathrm{A}(5.44 \pm 3.03 \mathrm{~km} /$ day $)$ and $\mathrm{A}(5.00 \pm 2.45 \mathrm{~km} /$ day $)$ groups $(\mathrm{p}=0.771)$. The effects of fructose on the hemodynamics, metabolic and morphological values of four groups, the effects of activity and whether two factors together make any effects were examined by two-way ANOVA test. It was found that systolic and diastolic blood pressure values were higher due to a fructose-rich diet $(\mathrm{p}=0.001, \mathrm{p}=0.002$ respectively; Table 3). The decrease in heart rate was observed due to the effects of activity $(\mathrm{p}=0.016)$. When the metabolic findings of the groups were evaluated, it was found that glucose, insulin, cholesterol, triglyceride and HDL values were high due to the fructose-rich diet (Table 4). No significant difference was found between HOMA-IR values of the groups, which are indicatives of insulin resistance (Table 4). The change in Lee index, associated with weight gain, $(\mathrm{p}=0.018)$ was determined to be related to physical activity (Table 2). In addition, liver weights were found to be high due to the effect of fructose-rich diet ( $\mathrm{p}=0.035)$ (Table 5). Total weight of heart, right and left ventricular 
weights, heart weight/tibia length (HW/TL) ratio used to determine cardiac hypertrophy
TAYFUR P., et al. and lung weights were not significantly different between the groups (Table 5).

Table 2. The effect of fructose and exercise on Lee index and the difference in fluid intake between the first and the last day of feeding period

\begin{tabular}{lccccccc} 
Groups & & & & & \multicolumn{3}{c}{ Two-way ANOVA $p$} \\
\cline { 6 - 8 } & $\mathrm{n}=7$ & $\mathrm{n}=7$ & $\mathrm{n}=7$ & $\begin{array}{c}\mathrm{F}+\mathrm{A} \\
\mathrm{n}=7\end{array}$ & $\begin{array}{c}\text { The effect } \\
\text { of } \\
\text { fructose }\end{array}$ & $\begin{array}{c}\text { The effect } \\
\text { of activity }\end{array}$ & $\begin{array}{c}\text { The effect of } \\
\text { fructose and } \\
\text { activity }\end{array}$ \\
\hline $\begin{array}{l}\text { Lee Index } \\
\begin{array}{l}\text { The difference } \\
\text { in fluid intake } \\
(\mathrm{mL})\end{array}\end{array}$ & $307 \pm 0.1$ & $296 \pm 0.1$ & $301 \pm 0.1$ & $300 \pm 0.1$ & 0.514 & 0.018 & 0.116 \\
\hline
\end{tabular}

Data are expressed as mean \pm standard deviation. $\mathrm{C}$ : Control group; A: Activity group; F: Fructose group; $\mathrm{F}+\mathrm{A}$ : Fructose+Activity group.

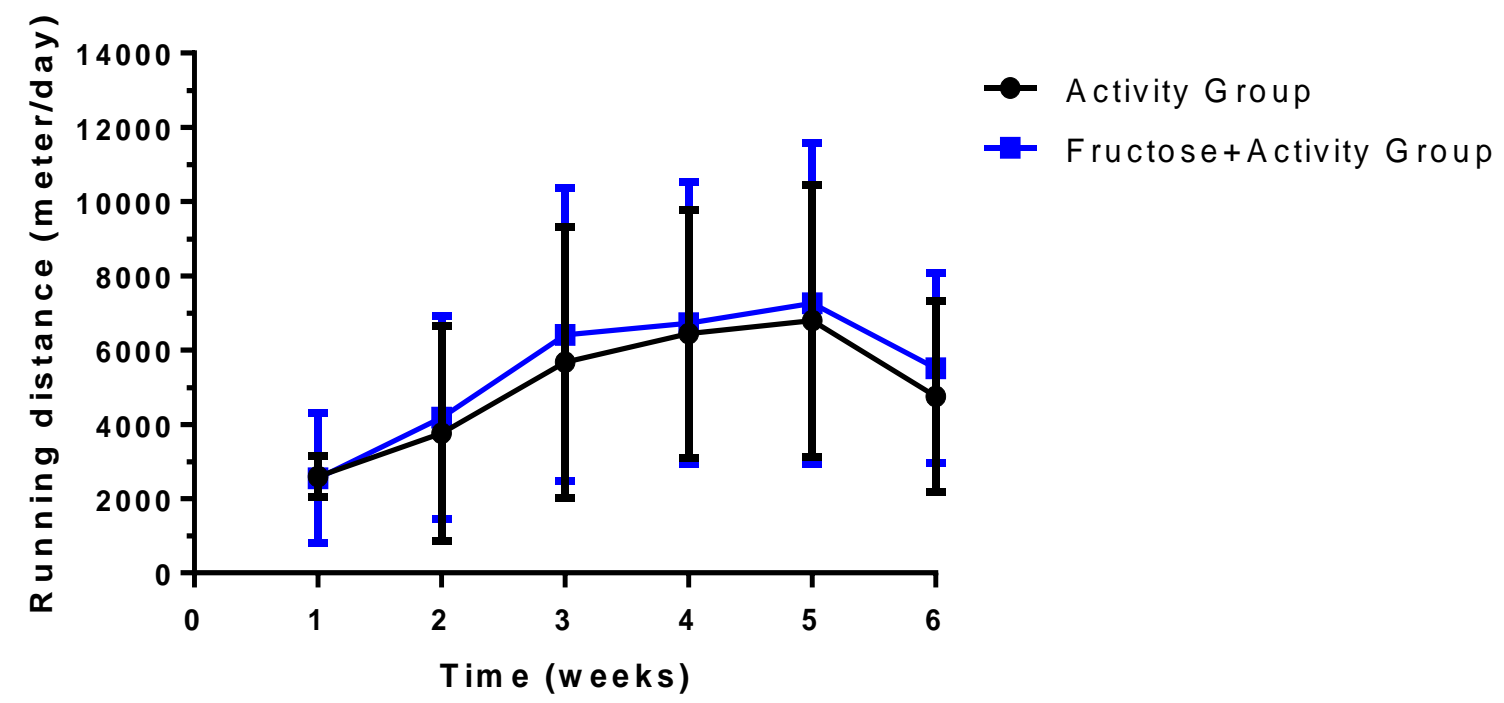

Figure 1. Measurements of wheel activity in the activity groups

Table 3. Blood pressures and heart rates of the groups

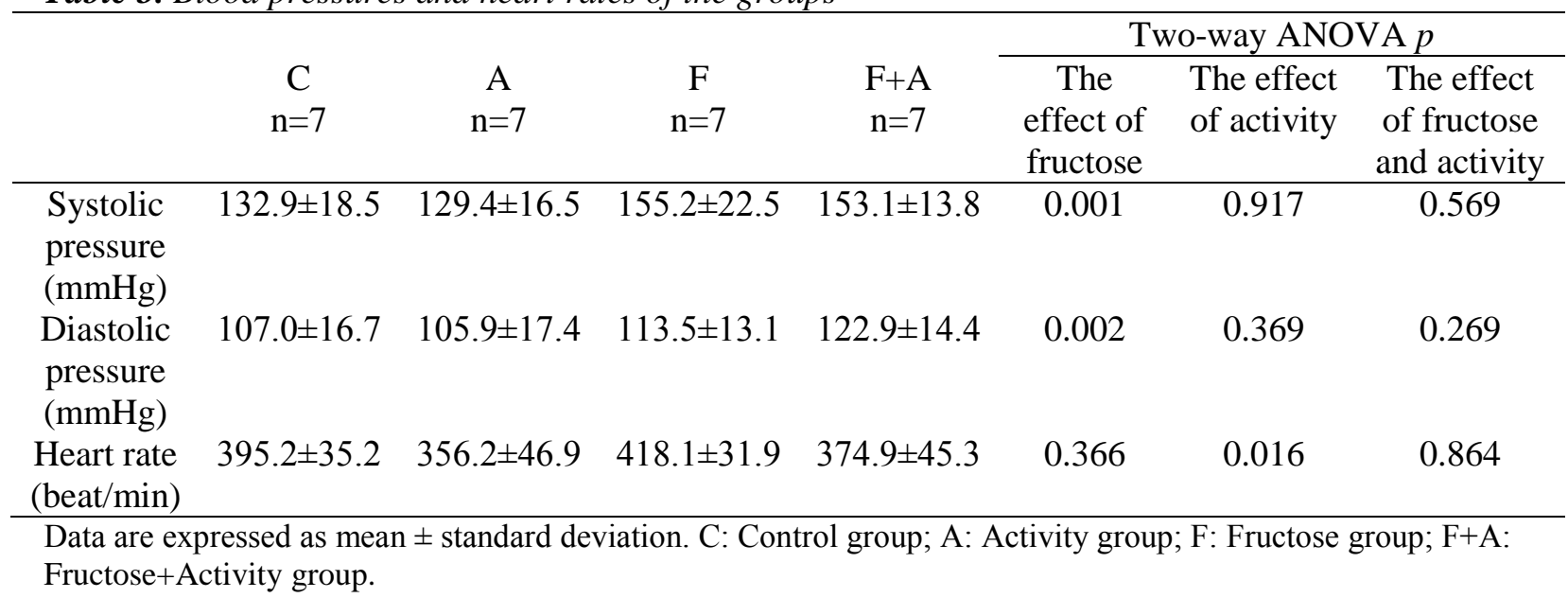


TAYFUR P., et al.

Table 4. Metabolic findings of the groups

\begin{tabular}{|c|c|c|c|c|c|c|c|}
\hline & \multirow[b]{2}{*}{$\underset{n=7}{C}$} & \multirow[b]{2}{*}{$\begin{array}{c}\mathrm{A} \\
\mathrm{n}=7\end{array}$} & \multirow[b]{2}{*}{$\begin{array}{c}\mathrm{F} \\
\mathrm{n}=7\end{array}$} & \multirow[b]{2}{*}{$\begin{array}{c}\mathrm{F}+\mathrm{A} \\
\mathrm{n}=7\end{array}$} & \multicolumn{3}{|c|}{ Two-way ANOVA $p$} \\
\hline & & & & & $\begin{array}{l}\text { The } \\
\text { effect of } \\
\text { fructose }\end{array}$ & $\begin{array}{l}\text { The } \\
\text { effect of } \\
\text { activity }\end{array}$ & $\begin{array}{l}\text { The } \\
\text { effect of } \\
\text { fructose } \\
\text { and } \\
\text { activity }\end{array}$ \\
\hline $\begin{array}{l}\text { Glucose } \\
\text { (mg/dl) }\end{array}$ & $104.0 \pm 16.4$ & $86.9 \pm 18.5$ & $117.4 \pm 21.0$ & $104.0 \pm 13.5$ & 0.041 & 0.266 & 0.426 \\
\hline $\begin{array}{l}\text { Insulin } \\
\text { (ng/mL) }\end{array}$ & $0.8 \pm 0.3$ & $0.8 \pm 0.3$ & $1.1 \pm 0.25$ & $0.8 \pm 0.3$ & 0.046 & 0.061 & 0.290 \\
\hline HOMA-IR & $4.84 \pm 2.16$ & $4.44 \pm 2.14$ & $3.07 \pm 2.99$ & $4.67 \pm 2.6$ & 0.466 & 0.565 & 0.190 \\
\hline $\begin{array}{c}\text { Total } \\
\text { cholesterol } \\
(\mathrm{mg} / \mathrm{dl})\end{array}$ & $58.0 \pm 12.9$ & $42.1 \pm 5.0$ & $72.4 \pm 6.1$ & $75.6 \pm 13.4$ & 0.001 & 0.363 & 0.198 \\
\hline $\begin{array}{l}\text { Triglyceride } \\
\text { (mg/dl) }\end{array}$ & $42.1 \pm 21.8$ & $61.7 \pm 35.3$ & $127.7 \pm 46.9$ & $90.6 \pm 45.5$ & 0.001 & 0.204 & 0.446 \\
\hline $\begin{array}{l}\mathrm{HDL} \\
(\mathrm{mg} / \mathrm{dl})\end{array}$ & $33.9 \pm 7.6$ & $25.9 \pm 4.1$ & $40.4 \pm 3.0$ & $42.6 \pm 6.0$ & 0.001 & 0.618 & 0.272 \\
\hline $\begin{array}{l}\text { LDL } \\
(\mathrm{mg} / \mathrm{dl})\end{array}$ & $14.7 \pm 9.1$ & $3.9 \pm 5.5$ & $6.4 \pm 9.8$ & $14.9 \pm 7.8$ & 0.201 & 0.854 & 0.066 \\
\hline
\end{tabular}

Data are expressed as mean \pm standard deviation. C: Control group; A: Activity group; F: Fructose group; F+A: Fructose+Activity group. HDL: High-density lipoprotein; LDL: Low-density lipoprotein. HOMA-IR:

Homeostasis assessment model of insulin resistance.

Table 5. Morphological evaluations of the groups regarding heart, liver and lung

\begin{tabular}{|c|c|c|c|c|c|c|c|}
\hline & \multirow[b]{2}{*}{$\begin{array}{c}\mathrm{C} \\
\mathrm{n}=7\end{array}$} & \multirow[b]{2}{*}{$\begin{array}{c}\mathrm{A} \\
\mathrm{n}=7\end{array}$} & \multirow[b]{2}{*}{$\begin{array}{c}\mathrm{F} \\
\mathrm{n}=7\end{array}$} & \multirow[b]{2}{*}{$\begin{array}{l}F+A \\
n=7\end{array}$} & \multicolumn{3}{|c|}{ Two-way ANOVA $p$} \\
\hline & & & & & $\begin{array}{c}\text { The effect } \\
\text { of } \\
\text { fructose }\end{array}$ & $\begin{array}{l}\text { The effect } \\
\text { of activity }\end{array}$ & $\begin{array}{c}\text { The effect } \\
\text { of } \\
\text { fructose } \\
\text { and } \\
\text { activity }\end{array}$ \\
\hline $\begin{array}{c}\text { Total } \\
\text { heart } \\
\text { weight }(\mathrm{g})\end{array}$ & $0.92 \pm 0.11$ & $0.92 \pm 0.07$ & $0.88 \pm 0.06$ & $0.95 \pm 0.10$ & 0.193 & 0.303 & 0.377 \\
\hline $\begin{array}{l}\text { Right } \\
\text { ventricle } \\
\text { weight }(\mathrm{g})\end{array}$ & $0.17 \pm 0.32$ & $0.18 \pm 0.04$ & $0.17 \pm 0.05$ & $0.18 \pm 0.02$ & 0.564 & 0.912 & 0.480 \\
\hline $\begin{array}{c}\text { Left } \\
\text { ventricle } \\
\text { weight }(\mathrm{g})\end{array}$ & $0.63 \pm 0.06$ & $0.67 \pm 0.65$ & $0.64 \pm 0.08$ & $0.69 \pm 0.09$ & 0.454 & 0.207 & 0.240 \\
\hline $\begin{array}{c}\text { Liver } \\
\text { weight }(\mathrm{g})\end{array}$ & $9.0 \pm 0.9$ & $9.5 \pm 1.2$ & $10.7 \pm 0.8$ & $10.9 \pm 2.4$ & 0.035 & 0.919 & 0.964 \\
\hline $\begin{array}{c}\text { Lung } \\
\text { weight }(g)\end{array}$ & $1.37 \pm 0.36$ & $1.53 \pm 0.84$ & $1.45 \pm 0.05$ & $1.39 \pm 0.12$ & 0.583 & 0.959 & 0.431 \\
\hline $\begin{array}{l}\mathrm{HW} / \mathrm{TL} \\
(\mathrm{mg} / \mathrm{mm})\end{array}$ & $0.2 \pm 0.0$ & $0.2 \pm 0.0$ & $0.2 \pm 0.0$ & $0.2 \pm 0.0$ & 0.048 & 0.503 & 0.373 \\
\hline
\end{tabular}

Data are expressed as mean \pm standard deviation. C: Control group; A: Activity group; F: Fructose group; F+A: Fructose+Activity group. HW: Heart weight; TL: Tibia length.

\section{DISCUSSION}

In this study, voluntary physical activity was found to be effective in decreasing the weight gain and resting heart rate in the development of metabolic syndrome induced by adding fructose to drinking water for six weeks in female rats. However, voluntary physical activity in female rats did not show any significant change in blood pressure, blood glucose and lipid levels due to a fructose-rich diet. 
The running wheel apparatus used for voluntary exercise enables experimental animals to perform physical activity in their living environments. Voluntary wheel running is preferred because it is self-motivating, allows for long-term activity, and can be performed without stress. In the studies using the rotating wheel, different animal species can perform activities at various levels (7). Previously reported that rats were able to walkrun for a maximum of $43 \mathrm{~km}$, wild mice for 31 $\mathrm{km}$, laboratory mice for $16 \mathrm{~km}$, golden hamsters for $9 \mathrm{~km}$, and gerbil for $8 \mathrm{~km}$ per 24 hours (9). In our study, the rats walked between 1.2 and $9 \mathrm{~km}$ per day. This walking distance covers a fairly wide range. The results of a recent study in female rats for the cause of this wide range of voluntary exercise behaviors suggest that voluntary exercise with a greater running distance is associated with an increase in the function of N-Methyl-D-aspartate receptors in the nucleus accumbens (17). In recent years, some studies conducted to evaluate the voluntary exercise of rats in different groups with similar activity levels. For example, in a study by Rattanavichit et al. (12), rats that covered an average distance of 5-8 $\mathrm{km}$ per day were selected for evaluating voluntary physical activity levels. In our study, all rats were evaluated without limitation in terms of voluntary activity. Thus, voluntary physical activity at all levels of rats was evaluated in this study.

Metabolic syndrome findings such as increased glucose intolerance, insulin resistance, hyperinsulinemia, hypertension, dyslipidemia have been shown in laboratory animals fed with a fructose-rich diet (18). The amount of fructose, the mode of administration or the duration of administration were different in the previous experimental studies. For example, male Spraque-Dawley rats fed with $60 \%$ fructose diet showed significant metabolic effects than the rats were given $10 \%$ fructose in drinking water in a previous study (19). However, no difference has been observed in serum glucose, insulin and lipid values rats fed with $10 \%$ fructose in drinking water between the control group in the study by Moura et al. (18). Similar to this finding, we did not find a significant change in blood glucose and lipid levels when we added $10 \%$ fructose to drinking water, in our previous study (20). In the present study, we observed increased serum glucose, insulin, cholesterol, triglyceride and HDL levels after fructose-rich diet for six
TAYFUR P., et al. weeks. However, we observed that voluntary physical activity did not cause a significant change in increasing metabolic parameters except of body weight.

In our study, the difference in fluid intake between the first and the last day of the experiment has significantly increased in the fructose groups ( $\mathrm{F}$ and $\mathrm{F}+\mathrm{A}$ group) (Table 2). This increase may be related with the using appropriate amount of fructose in drinking water. In a study by Mamikutty et al. (21) which was given male rats $20 \%$ and $25 \%$ fructose in drinking water showed that rats consumed a higher amount of $20 \%$ fructose in drinking water than $25 \%$ fructose. In addition, rats fed with $20 \%$ fructose in drinking water consumed more water than the rats in the control group. This was suggested as that the rats liked the taste of $20 \%$ fructose in drinking water than $25 \%$ fructose. In previous studies, the amount of fructose given by drinking water was varied between 5-40\% (20-23). In our study, fructose was given by adding $20 \%$ to drinking water and the same feed content in a diet was used in all groups (Table 1). However, although the fluid intake was determined, daily feed intake and energy values could not be determined. Therefore, the effect of feed intake on the process of weight gain could not be shown between groups.

According to the findings of our study, no significant changes were detected between the groups in terms of insulin resistance, HOMAIR values due to a fructose-rich diet or exercise. In a previous study, it was suggested that voluntary activity had a decreasing effect on HOMA-IR in diabetic rats, caused a decrease in insulin resistance, and had a protective effect on cardiac tissue by increasing the protein expression of vascular endothelial growth factor-A (24). A lower limit was determined for voluntary exercise and the findings of rats covering a shorter distance were excluded in some of the studies. For example, regarding the effect of voluntary exercise on insulin resistance, Rattanavichit et al. (12) did not evaluate the rats covering less than $5 \mathrm{~km}$ per day. In rats fed with $10 \%$ fructose in drinking water, it was shown that voluntary exercise decreased the amount of visceral fat and was reported to be a contributing factor in regulating insulin sensitivity. In our study, the reason of not detecting a significant change in HOMA-IR levels may be due to the evaluation of all the 
rats without any lower limit for voluntary physical activity in present study.

In conclusion, according to the results of this study, voluntary physical activity decreases obesity and heart rate however, it does not cause important changes in blood pressure, blood glucose and lipid homeostasis during a fructose-rich diet in female rats.

\section{ACKNOWLEDGEMENTS}

We would like to thank Dr. Oktay Kaya (University of Trakya, Turkey) for his assistance in laboratory measurements.

\section{FUNDING}

This study was supported by Trakya University Scientific Research Projects Unit (TUBAP 2016/84).

\section{REFERENCES}

1. Hecker, PA., Mapanga, RF., Kimar, CP., Ribeiro, RF., Brown, BH., O'Connell, KA., Cox, JW., Shekar, KC., Asemu, G., Essop, MF., Stanley, W.C. Effects of glucose-6phosphate dehydrogenase deficiency on the metabolic and cardiac responses to obesogenic or high-fructose diets, Am J Physiol Endocrinol Metab. 303(8):959-72, 2012.

https://doi.org/10.1152/ajpendo.00202.2012

2. Thorens, B., Mueckler, M. Glucose transporters in the 21st Century, Am J Physiol Endocrinol Metab. 298(2):141-5, 2010.

https://doi.org/10.1152/ajpendo.00712.2009

3. Kitiş, Y., Gümüş, Y. Frequency and affecting factors of metabolic syndrome in women older than 20 years of age, Anadolu Kardiyol Derg. 10:111-9, 2010. https://doi.org/10.5152/akd.2010.033.

4. Axelsen, LN., Lademann, JB., Petersen, JS., Holstein-Rathlou, NH., Ploug, T., Prats, C., Pedersen, HD., Kjolbye, AL. Cardiac and metabolic changes in long-term high fructose-fat fed rats with severe obesity and extensive intramyocardial lipid accumulation, Am J Physiol Regul Integr Comp Physiol, 298(6):1560-70, 2010. https://doi.org/10.1152/ajpregu.00392.2009.

5. Moraes-Silva, IC., Mostarda, C., Moreira, ED., Silva, KA., dos Santos, F., de Angelis, K., Farah Vde, M., Irigoyen, MC. Preventive role of exercise training in autonomic, hemodynamic, and metabolic parameters in rats under high risk of
TAYFUR P., et al. metabolic syndrome development, J Appl Physiol. $\quad 114(6): 786-91, \quad 2013$. https://doi.org/10.1152/japplfiziol.00586.20 12.

6. Mostarda, C., Moraes-Silva, IC., Salemi, VM., Machi, JF., Rodrigues, B., De Angelis, K., Farah Vde, M., Irigoyen, MC. Exercise training prevents diastolic dysfunction induced by metabolic syndrome in rats, Clinics. 67(7):815-20, 2012. https://doi.org/10.6061/clinics/2012(07)18.

7. Garland, T., Schutz, H., Chappell, MA., Keeney, BK., Meek, TH., Copes, LE., Acosta, W., Drenowatz, C., Maciel, RC., van Dijk, G., Kotz, CM., Eisenmann, JC. The biological control of voluntary exercise, spontaneous physical activity and daily energy expenditure in relation to obesity: human and rodent perspectives, $J$ Exp Biol. 214:206-29, 2011. https://doi.org/10.1242/jeb.048397.

8. Lynch, CA., Porter, B., Butler, TR. Access to voluntary running wheel exercise: Prevention of anxiety-like behavior in chronically stressed rats, but potentiation of ethanol intake/preference, Physiol. Behav. 206:118-124,

2019. https://doi.org/10.1016/j.physbeh.2019.03.0 28.

9. Sherwin, CM. Voluntary wheel running: a review and novel interpretation, Anim Behav. 56(1):11-27, 1998.

10.Garvey, SM., Russ, DW., Skelding, MB., Dugle, JE., Edens, NK. Molecular and metabolomic effects of voluntary running wheel activity on skeletal muscle in late middle-aged rats, Physiol Rep. 3(2):e12319, 2015. https://doi.org/10.14814/phy2.12319.

11. Ghorbanzadeh, V., Mohammadi, M., Mohaddes, G., Dariushnejad, H., Chodari, L., Mohammadi, S. Protective effect of crocin and voluntary exercise against oxidative stress in the heart of high-fat dietinduced type 2 diabetic rats, Physiol Int. 103(4):459-68, 2016. https://doi.org/10.1556/2060.103.2016.4.6.

12.Rattanavichit, Y., Buniam, J., Surapongchai, J., Saengsirisuwan, V. Voluntary exercise opposes insulin resistance of skeletal muscle glucose transport during liquid fructose ingestion in rats, J Biochem Physiol. 74(3):455-66, 2018. https://doi.org/10.1007/s13105-0180639-8. 
13.Lee, JR., Tapia, MA., Nelson, JR., Moore, JM., Gereau, GB., Childs, TE., VieiraPotter, VJ., Booth, VF., Will, MJ. Sex dependent effects of physical activity on diet preference in rats selectively bred for high or low levels of voluntary wheel running, Behav Brain Res. 359:95-103, 2019. https://doi.org/10.1016/j.bbr.2018.10.018.

14.Sasse, SK., Greenwood, BN. Masini, CV., Nyhuis, TJ., Fleshner, M., Day, HE., Campeau, S. Chronic voluntary wheel running facilitates corticosterone response habituation to repeated audiogenic stress exposure in male rats, Stress. 11(6):425-37, 2008.

https://doi.org/10.1080/1025389080188745 3.

15.Friedewald, WT., Levy, RI., Fredrickson, DS. Estimation of the concentration of lowdensity lipoprotein cholesterol in plasma, without use of the preparative ultracentrifuge, Clin Chem. 18(6):499-502, 1972.

16.Antunes, LC., Elkfury, JL., Jornada, MN., Foletto, KC., Bertoluci, MC. Validation of HOMA-IR in a model of insulin-resistance induced by a high-fat diet in Wistar rats, Arch Endocrinol Metab. 60(2):138-142, $2016 . \quad$ https://doi.org/10.1590/23593997000000169.

17.Grigsby, KB., Kovarik, CM., Rottinghaus, GE., Booth, FW. High and low nightly running behavior associates with nucleus accumbens N-Methyl-d-aspartate receptor (NMDAR) NR1 subunit expression and NMDAR functional differences, Neurosci Lett. $\quad 671: 50-55, \quad 2018$. https://doi.org/10.1016/j.neulet.2018.02.011

18.de Moura, RF., Ribeiro, C., de Oliveira, JA., Stevanato, E., de Mello, MA. Metabolic syndrome signs in Wistar rats submitted to different high-fructose ingestion protocols, Br J Nutr. 101(8):117884, 2009. https://doi.org/10.1017/S000711450806677 4.
TAYFUR P., et al.

19.Sanchez-Lozada, LG., Tapia, E., Jiménez, A., Bautista, P., Cristóbal, M., Nepomuceno, T., Soto, V., Avila-Casado, C., Nakagawa, T., Johnson, RJ., HerreraAcosta, J., Franco, M. Fructose-induced metabolic syndrome is associated with glomerular hypertension and renal microvascular damage in rats, Am J Physiol Renal Physiol. 292(1):423-29, 2007. https://doi.org/10.1152/ajprenal.00124.2006

20.Tayfur, P., Palabıyık, O., Uzun, N., Süt, N., Vardar, AV. Effect of voluntary physical activity on metabolic and cardiac function in fructose-rich fed rats, Genel Tip Dergisi. 29(2):65-72, 2019. https://doi.org/10.15321/GenelTipDer.2019 253583.

21.Mamikutty, N., Thent, ZC., Sapri,SR., Sahruddin, NN., Mohd Yusof, MR., Haji Suhaimi F. The establishment of metabolic syndrome model by induction of fructose drinking water in male Wistar rats, Biomed Res Int. 2014(4):263897, 2014. https://doi.org/10.1155/2014/263897.

22.Cardinali, DP., Bernasconi, PA., Reynoso, R. Toso, CF., Scacchi, P. Melatonin may curtail the metabolic syndrome: studies on initial and fully established fructoseinduced metabolic syndrome in rats, Int $J$ Mol Sci. 14(2):2502-14, 2013. https://doi.org/10.3390/ijms14022502.

23.Wilson, RD., Islam, MS. Fructose-fed streptozotocin-injected rat: an alternative model for type 2 diabetes, Pharmacol Rep. 64(1):129-39, 2012. https://doi.org/10.1016/s17341140(12)70739-9.

24.Ghorbanzadeh, V., Mohammadi, M., Dariushnejad, H., Chodari, L., Mohaddes, G. Effects of crocin and voluntary exercise, alone or combined, on heart VEGF-A and HOMA-IR of HFD/STZ induced type 2 diabetic rats, $J$ Endocrinol Invest. 39(10):1179-86, 2016. https://doi.org/10.1007/s40618-016-0456-2. 